\title{
SISTEM PALANG PINTU PERLINTASAN KERETA API OTOMATIS DENGAN KOMUNIKASI WIRELESS BERBASIS ARDUINO
}

\author{
Medilla Kusriyanto ${ }^{1}$, Nendy Wismoyo ${ }^{2}$ \\ Jurusan Teknik Elektro, Fakultas Teknologi Industri, Universitas Islam Indonesia \\ Jl. Kaliurang Km 14.5, Ngemplak, Sleman, Yogyakarta 55584 \\ E-Mail :medilla@uii.ac.id
}

\begin{abstract}
Trains are a means of transportation of interest to the public in Indonesia. In addition to fast, the cost and convenience of service on the train became one of the reasons for the selection of this transportation. Accidents at railway crossings are common in Indonesia. One reason is the absence of a doorstop in the railway crossing. In this research, we try to develop the closing and opening tool of train railway crossing automatically. This device is equipped with vibration sensor and infrared sensor to detect train arrival. The sensor readout signal will be processed by arduino UNO and sent to the control center using wireless $n R F 24 l 01+P A+L N A$ module. The signal will be received by the control module using the same receiver module and will be processed by arduino mega 2560 to open and close the railway crossing door equipped with LED indicator. Based on the test results, the $n R F 24101+P A+L N A$ transceiver module can work at a distance of 940 meters with an average data transmission delay of 1.2952 seconds.
\end{abstract}

Keywords : Infrared Sensor, Vibration Sensor, Transceiver n RF24l01 + PA + LNA, Servo Motor, Buzzer, LED, Wireless.

\section{PENDAHULUAN}

Kereta api merupakan sarana transportasi yang dewasa ini diminati masyarakat. Peningkatan pelayanan dan kenyamanan penumpang menjadi salah satu daya tarik masyarakat untuk memilih sarana transportasi ini. Kecelakaan kereta api dengan model transportasi lain seringkali terjadi diperlintasan kereta api yang tidak atau belum mmeiliki penjaga pintu perlintasan. Dewasa ini banyak dikembangkan penelitian untuk otomasi pintu perlintasan dengan melibatkan mikrokontroller sebagai pusat pengendali data sensor dan penutup serta pembuka pintu perlintasan kereta api. Dalam penelitian ini dicoba untuk mengembangkan sistem penutup dan pembuka pintu perlintasan dengan melibatkan komunikasi nirkabel antara sensor pendeteksi kedatangan kereta api dan pusat kendali pintu perlintasan kereta api.

\section{TINJAUAN PUSTAKA}

Automatic Railway Gate and Crossing Control based Sensors \& Microcontroller (Ahmed, S.H dan Al Zuhairi, 2013) dalam penelitiannya menggunakan mikrokontroler 8052 untuk mengotomatisasi pintu persimpangan kereta api shingga palang pintu bekerja secara otomatis. Perangkat ini dilengkapi dengan sensor magnetik yang terpasang pada kedua sisi gerbang perlintasan untuk mendeteksi kedatangan kereta api. Bila sensor pada satu sisi gerbang perlintasan kereta api mendeteksi kedatangan kereta maka sensor ini akan mengirimkan sinyal ke mikrokontroler 8052 untuk menutup gerbang perlintasan. Pintu gerbang perlintasan akan tetap tertutup sampai kereta melewati perlintasan dan akan membuka kembali setelah sensor pada sisi lain dari perlintasan tidak mendeteksi keberadaan kereta api. 
Pressure Sensed Fast Response AntiCollision System for Automated Railway Gate Control (Biswas, S, Bhuiyan, R, Hoque, S, Hasan, R dan Khan, T, 2013) dalam penelitiannya menggunakan sensor tekanan untuk mengendalikan pintu palang perlintasan kereta api. Penelitian ini menggunakan mikrokontroler PIC 16F84A sebagai pusat pengolahan data sensor.

Sensor Based Automatic Control of Railway Gates (Khrisnamurti, K, Bobby, M, Vidya, V, Baby, E, 2015) dalam penelitiannya menggunakan 2 buah sensor inframerah untuk mendeteksi kedatangan kereta api dan sebuah sensor inframerah untuk mendeteksi keberangkatan kerta api. Penelitian ini dilengkapi dengan mikrokontroler arduino sebagai pusat pengolah data sensor dan pengatur gerakan motor untuk menutup dan membuka pintu perlintasan kereta api.

\subsection{Palang Pintu Perlintasan Kereta Api}

Palang pintu kereta api merupakan sarana dari PT. Kereta Api Indonesia (KAI) untuk mengatur atau mencegah pengendara kendaraan bermotor maupun pejalan kaki melintasi rel kereta api saat ada kereta api yang melintasi palang kereta.

\subsection{Arduino}

Arduino adalah pengendali mikro single-board yang bersifat open-source, diturunkan dari wiring platform, dirancang untuk memudahkan pengguna elektronik dalam berbagai bidang. Hardware dari arduino memiliki prosesor dan software nya memiliki bahasa pemrograman sendiri yaitu Arduino IDE.

Arduino Uno R3 merupakan sebuah board mikrokontroller yang didasarkan pada ATmega328 yang mempunyai kapasitas penyimpanan $32 \mathrm{~kb}$. Board arduino uno bekerja pada tegangan $5-12$ Volts. Arduino uno memiliki 20 pin Input / Output yang terdiri dari 14 pin digital dan 6 pin input analog. Arduino uno memuat semua yang dibutuhkan untuk menunjang mikrokontroler, sangat mudah menghubungkannya ke sebuah komputer dengan sebuah kabel USB, atau mensuplainya dengan sebuah adaptor AC (Alternating Current) ke DC (Direct Current) atau menggunakan baterai untuk menjalankannya. ATmega328 pada arduino uno hadir dengan sebuah bootloader yang memungkinkan untuk meng-upload kode baru ke ATmega328 tanpa menggunakan program hardware eksternal.

\subsection{Sensor Ultrasonic HC SRF-04}

Sensor infrared termasuk dalam kategori sensor biner, yaitu sensor yang menghasilkan output 1 atau 0 saja. Infra Red Sensor (IR Sensor) dapat digunakan untuk berbagai keperluan, misalnya untuk mendeteksi sebuah benda, mengukur panjang benda, dan lain - lain. Inframerah / Infrared merupakan radiasi elektromagnetik yang panjang gelombangnya lebih panjang dari cahaya yang nampak yaitu diantara 700 $\mathrm{nm}$ dan $1 \mathrm{~mm}$, tetapi lebih pendek dari radiasi gelombang radio.

Pada penelitian ini, sensor inframerah yang digunakan adalah Adjustable Range Infrared Sensor dengan tipe E18-DB80NK. Sensor ini memiliki jarak deteksi $3-80 \mathrm{~cm}$. Adjustable Range Infrared Sensor merupakan seperangkat pemancar dan penerima disalah satu sensor saklar photoelectric. Bentuk fiaik E18-DB80NK ditunjukkan pada gambar 2.1.

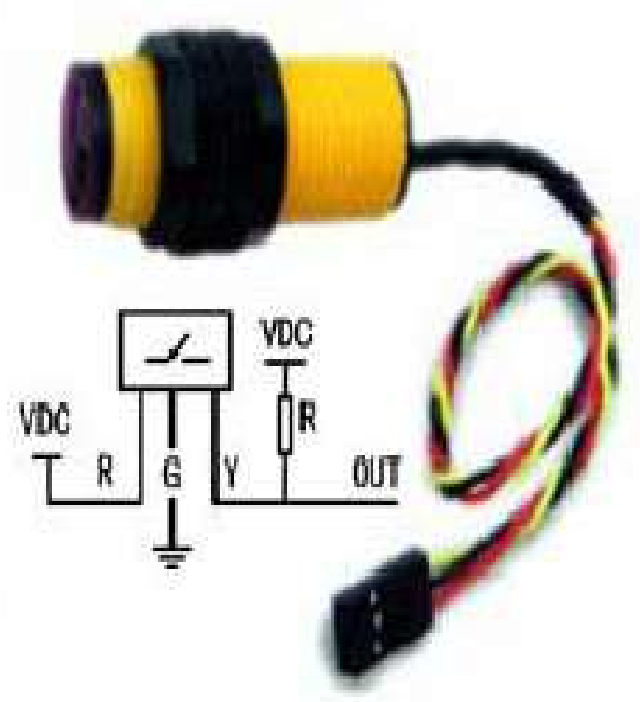

Gambar 1. Sensor Inframerah E18 - DB80NK. 


\subsection{Sensor Getaran SW-40}

Sensor getaran adalah suatu alat yang berfungsi untuk mendeteksi adanya getaran dan mengubahnya ke dalam sinyal listrik. Sensor getaran dibagi menjadi 2 macam yaitu sensor kontak dan sensor non - kontak. Sensor kontak, sensor ini disebut juga cassing measurement. Sensor yang digunakan adalah sensor seismic transduser, yaitu sensor yang digunakan untuk mengukur kecepatan dan percepatan. Untuk mengukur kecepatan menggunakan velocity probe dan velomitor probe, sedangkan untuk mengukur percepatan menggunakan sensor acceleration probe. Sedangkan, sensor non - kontak biasanya disebut Shaft Relative Measurement. Sensor yang digunakan adalah proximity probe (Eddy current probe). Untuk proxymity probe, yang diukur adalah perpindahannya. Untuk sensor non-kontak, probe dan mesin atau media lainnya dalam penggunaannya tidak bersentuhan secara langsung.

Pada penelitian ini, sensor getaran yang digunakan adalah modul sensor getaran SW-420. Modul sensor getaran ini dapat diaplikasikan pada sistem keamanan, deteksi gempa, pendeteksi malfungsi pada sistem mekanik, dan lain - lain. Inti dari modul ini adalah komponen pendeteksi getaran SW-420 yang bereaksi terhadap getaran dari berbagai sudut. Pada kondisi statis atau tanpa getaran, komponen elektronika ini berada pada kondisi menutup (Normally Closed) dan bersifat konduktif. Sebaliknya, pada kondisi terguncang atau terpapar getaran saklar akan membuka lalu menutup dengan kecepatan pengalihan yang proporsional dengan kekerapan guncangan. Bentuk fisik sensor getaran ditunjukkan pada gambar 2.2.

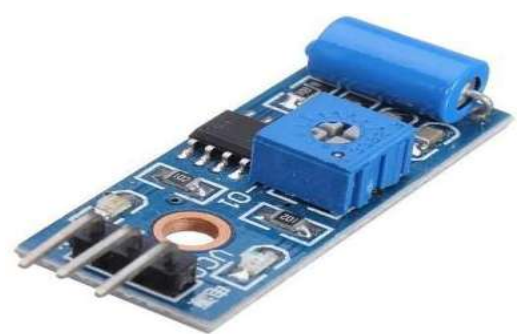

Gambar 2. Sensor Getaran SW-40.

\subsection{Modul Transceiver nRF24101}

Pada penelitian ini menggunakan modul transceiver nRF24L01+PA+LNA. Modul transceiver ini dilengkapi dengan tambahan PA (Power Amplifier) dan LNA (Low Noise Amplifier), sehingga jarak transfer data dapat semakin jauh dan lebih stabil. Area yang dapat dijangkau oleh modul transceiver ini mencapai radius 1000 meter pada tempat terbuka tanpa hambatan. Modul ini memiliki 3 pilihan opsi data rate yaitu $250 \mathrm{Kbps}$, $1 \mathrm{Mbps}$, dan $2 \mathrm{Mbps}$. Data pada modul transceiver ini dimodulasi dengan GFSK (Gaussian Frequency Shift Keying), yaitu tipe modulasi pergeseran frekuensi yang mentransmisikan data secara lebih presisi.

Modul transceiver nRF24L01 + PA + LNA memadukan penerima dan pemancar frekuensi radio (RF / Radio Frequency Transceiver) berfrekuensi $2.4 \mathrm{GHz}, \mathrm{RF}$ synthesizer, dan baseband logic termasuk protokol Enhanced ShockBurst ${ }^{\mathrm{TM}}$ hardware protocol accelerator yang mendukung antarmuka SPI (Serial Peripheral Interface) berkecepatan tinggi untuk pengendalian aplikasi. Antarmuka SPI ini dengan mudah dapat dihubungkan dengan pin - pin SPI pada modul arduino. Modul ini memiliki tegangan kerja antara 1,9 sampai 3,6 volt. Bentuk fisik dari modul ini dapat dilihat pada gambar 2.3.

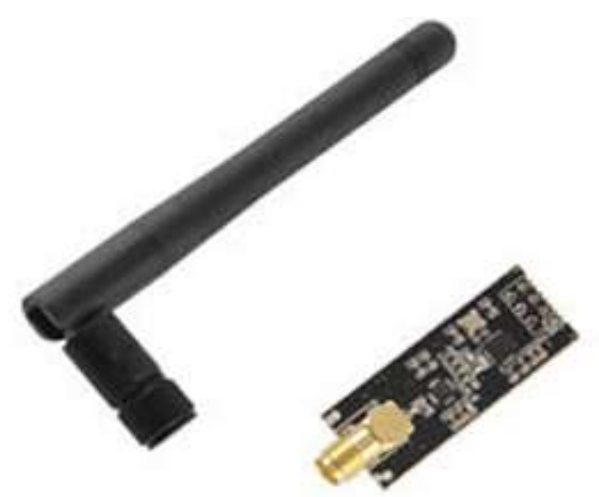

Gambar 3. Modul Transceiver bRF24L01.

\subsection{Motor Servo}

Motor servo menggunakan sistem umpan balik tertutup, dimana posisi dari motor akan diinformasikan kembali ke rangkaian kontrol yang ada didalam motor 
servo. Motor ini terdiri dari sebuah motor DC, serangkaian gear, potensiometer dan rangkaian kontrol. Secara umum terdapat 2 jenis motor servo, yaitu motor servo standard dan motor servo continous. Servo motor tipe standar hanya mampu berputar 180 derajat. Motor servo standard sering dipakai pada sistem robotika, misalnya untuk membuat "Robot Arm" (Robot Lengan). Sedangkan, Servo motor continuous dapat berputar sebesar 360 derajat. motor servo continous sering dipakai untuk Mobile Robot. Pengendalian gerakan motor servo dapat dilakukan dengan menggunakan metode PWM (Pulse Width Modulation). Teknik ini menggunakan sistem lebar pulsa untuk mengemudikan putaran motor.

Pada penelitian ini, motor servo yang digunakan adalah motor servo yang berjenis standar, tipenya yaitu motor servo Tower Pro SG90. Motor servo ini hanya mampu berputar 180 derajat, 90 derajat searah jarum jam dan 90 derajat berlawanan arah jarum jam.

\subsection{Buzzer}

Buzzer adalah sebuah transduser yang berfungsi untuk merubah energi listrik menjadi energi suara. Fungsi buzzer adalah sama seperti speaker, yaitu menghasilkan suara. Namun buzzer hanya mampu menghasilkan suara berfrekuensi tinggi, sedangkan speaker mampu untuk menghasilkan frekuensi tinggi dan rendah. pada diafragma dan kemudian kumparan tersebut dialiri arus sehingga menjadi elektromagnet, kumparan tadi akan tertarik ke dalam atau keluar, tergantung dari arah arus dan polaritas magnetnya, karena kumparan dipasang pada diafragma maka setiap gerakan kumparan akan menggerakkan diafragma secara bolak balik sehingga membuat udara bergetar yang akan menghasilkan suara. Dalam penelitian ini, buzzer yang digunakan adalah KY-012 active buzzer module. Buzzer KY012 ini memiliki kelebihan yaitu buzzer ini lebih mudah dan praktis digunakan, karena sudah dalam bentuk modul.

\subsection{Sistem Perancangan}

Perancangan "Sistem Palang Pintu Perlintasan Kereta Api Dengan Komunikasi Wireless Berbasis Arduino" ini dibuat berdasarkan diagram blok sistem yang terdapat pada gambar 3.1.

\subsubsection{Perancangan Arduino dan Transceiver nRF24L01}

Pada perancangan sistem ini menggunakan 2 buah arduino uno. Kedua buah arduino uno tersebut dihubungkan dengan transceiver nRF24101 untuk digunakan sebagai trasmitter. Dalam menghubungkan transceiver nRF24101 ke arduino uno harus sesuai dengan konfigurasi pin yang terdapat pada datasheet, yaitu letak pin SCK berada pada pin 13, MOSI pada pin 11, dan MISO pada

Buzzer terdiri dari kumparan yang terpasang

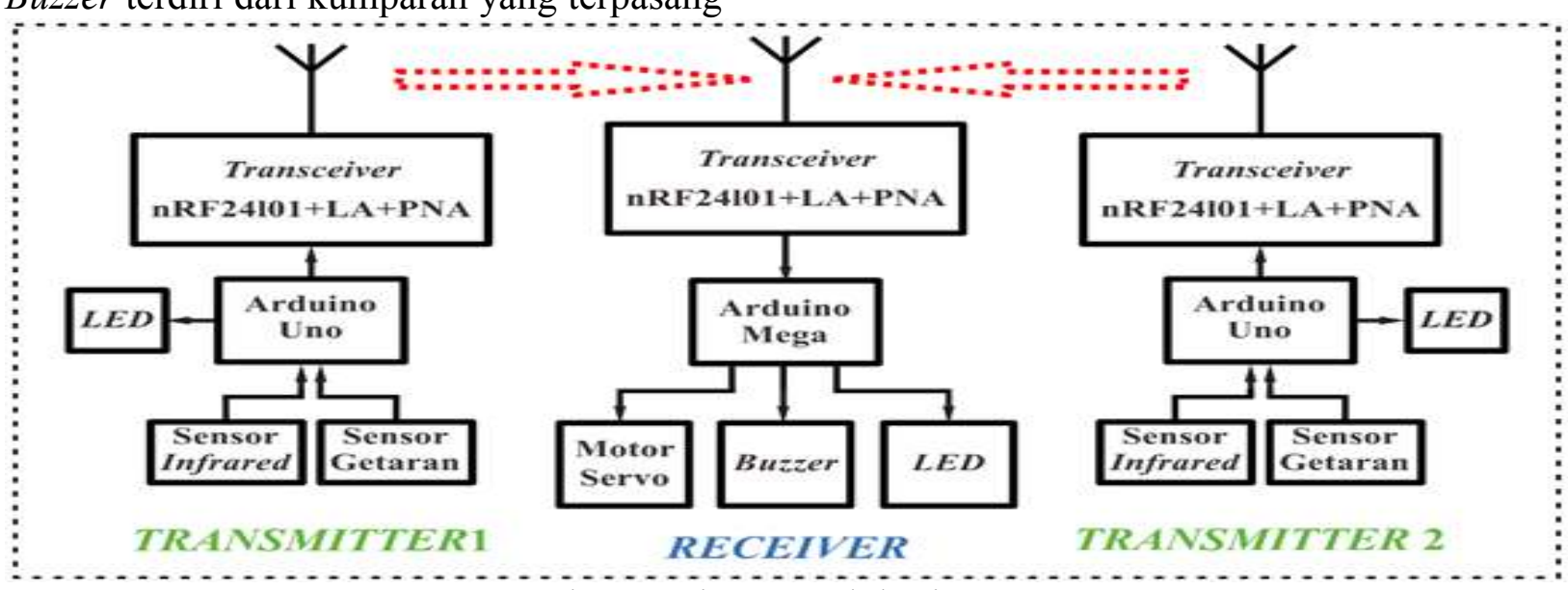

Gambar 4. Diagram Blok Sistem. 
pin 12. Untuk pin $\mathrm{CE}$ diletakan pada pin nomor 7 dan pin CSN diletakan pada pin nomor 8. Untuk pin IRQ tidak dihubungkan kemanapun. Jika letak pin SCK, MOSI, dan MISO tidak sesuai, maka transceiver nRF24101 tidak dapat digunakan untuk mengirim data ataupun menerima data. Rangkaian arduino UNO dengan transceiver nRF24L01 ditunjukkan pada gambar 5 .

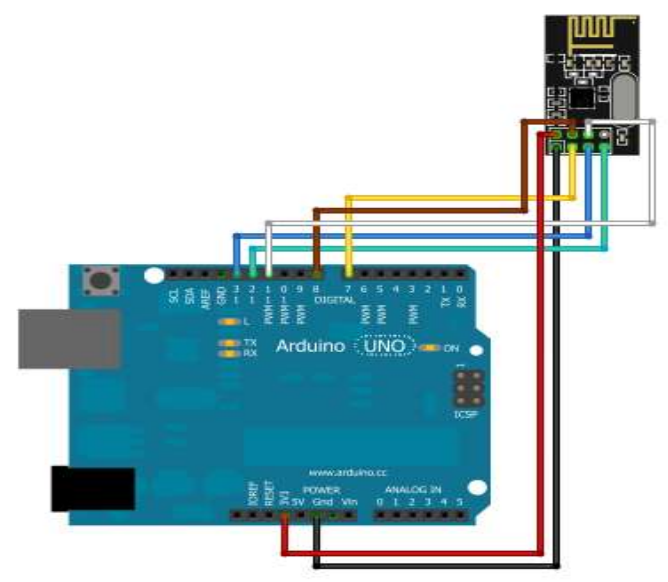

Gambar 5. Rangkaian Modul nRF24L01.

\subsubsection{Perancangan Arduino Uno dengan Sensor Infrared E18-D80NK}

Pada perancangan sistem ini, sensor infrared E18-D80NK digunakan untuk mendeteksi adanya kereta yang melintas melewati sensor. Ketika kereta melewati sensor, maka LED pada sensor akan menyala dan sensor berada pada kondisi High. Sebaliknya, jika tidak ada kereta yang melewati sensor, maka LED pada sensor mati dan sensor berada pada kondisi Low. Output dari sensor infrared ini dapat langsung dihubungkan ke mikrokontroller arduino untuk mendeteksi keadaan sensor sedang High atau Low, sehingga dapat diketahui apakah ada obyek yang melintasi sensor atau tidak. Sensor ini memiliki 3 pin yang harus dihubungkan ke arduino yaitu Vec (5 V), ground, dan sinyal. Gambar rangkaian arduino uno $\mathrm{r} 3$ dan sensor inframerah ditunjukkan pada gambar 6 .

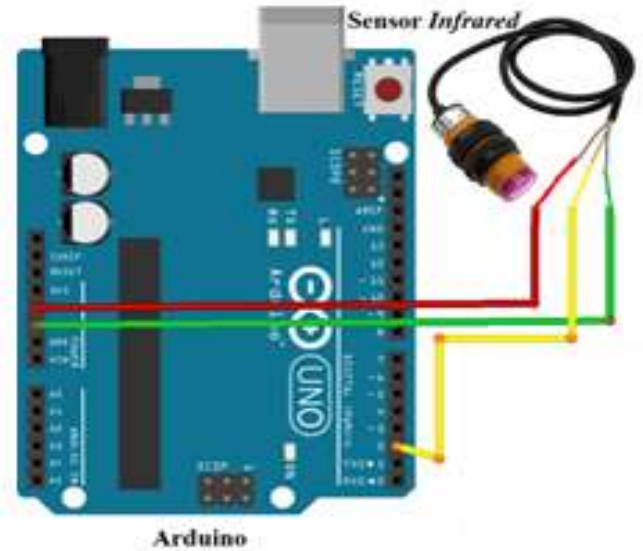

Gambar 6. Sensor Inframerah dan Arduino Uno R3.

\subsubsection{Rangkaian Modul Suara DFMini Player dan Arduino Mega 2560}

Pada perancangan sistem ini, sensor getaran SW-420 digunakan untuk mendeteksi getaran yang dihasilkan kereta api ketika kereta api melewati sensor getaran tersebut. Cara kerja sensor getaran ini yaitu jika sensor tidak mendeteksi adanya getaran dari kereta api, maka sensor getaran akan terhubung, nilai output rendah / kondisi Low, dan lampu indikator pada sensor akan menyala. Sebaliknya, jika sensor mendeteksi adanya getaran dari kereta api, maka sensor getaran akan terputus atau tidak terhubung, nilai output tinggi / kondisi High, dan lampu indikator pada sensor akan mati. Output dari sensor getaran ini dapat langsung dihubungkan ke mikrokontroller arduino untuk mendeteksi nilai rendah / Low dan tinggi / High, sehingga dapat diketahui apakah sedang terjadi getaran atau tidak. Sensor ini memiliki 3 pin yang harus dihubungkan ke arduino yaitu Vec (5 V), ground, dan sinyal. Rangkaian arduino UNO dengan sensor getaran ditunjukkan pada gambar 7 . 


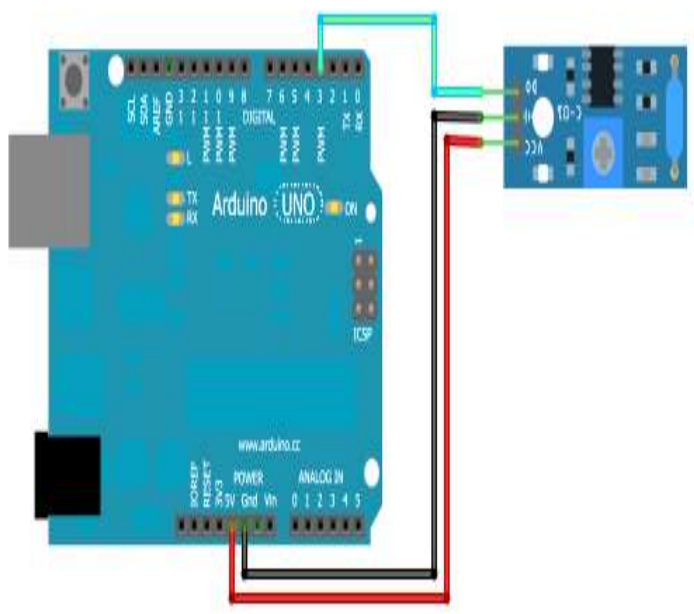

Gambar 7. Arduino UNO R3 dan Sensor Getaran SW 420.

\subsection{Perancangan Receiver}

Rangkaian receiver pada perancangan sistem ini terdiri dari Arduino mega 2560, Adaptor AC-DC 9V 1A, Modul Transceiver nRF24101, Motor Servo Tower Pro SG90, Buzzer KY-012 dan LED. Konfigurasi rangkaian pin pada receiver dapat dilihat pada gambar 8 .

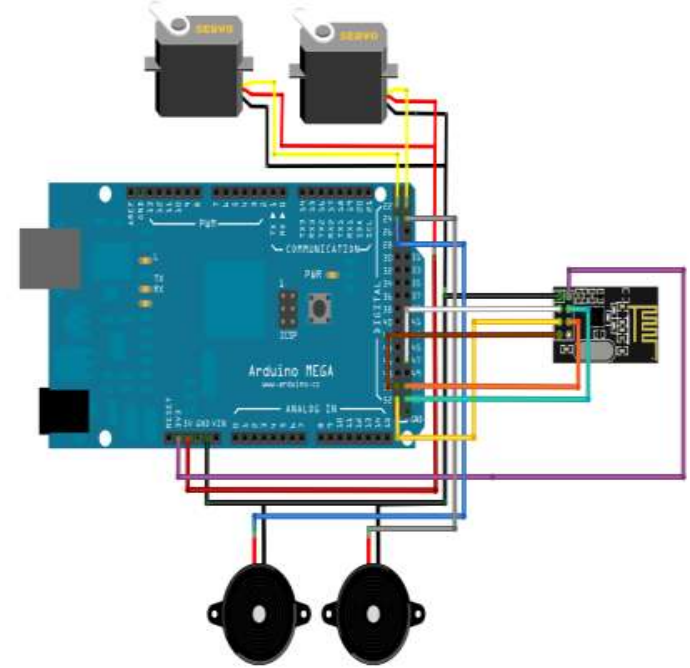

Gambar 8. Rangkaian Reciever.

\section{HASIL DAN PEMBAHASAN}

Miniatur palang pintu perlintasan kereta api yang digunakan pada penelitian ini disimulasikan dengan perangkat keras sebagaimana ditunjukkan pada gambar 9 .

\subsection{Pengujian Sensor Inframerah}

Pengujian sensor infrared ini dilakukan dengan cara mengukur jarak yang ada pada sensor infrared terhadap suatu obyek. Sesuai dengan datasheet, sensor ini mampu mendeteksi obyek dengan jarak maksimum $80 \mathrm{~cm}$. Namun, setelah dilakukan percobaan sensor ini tidak mampu mendeteksi obyek

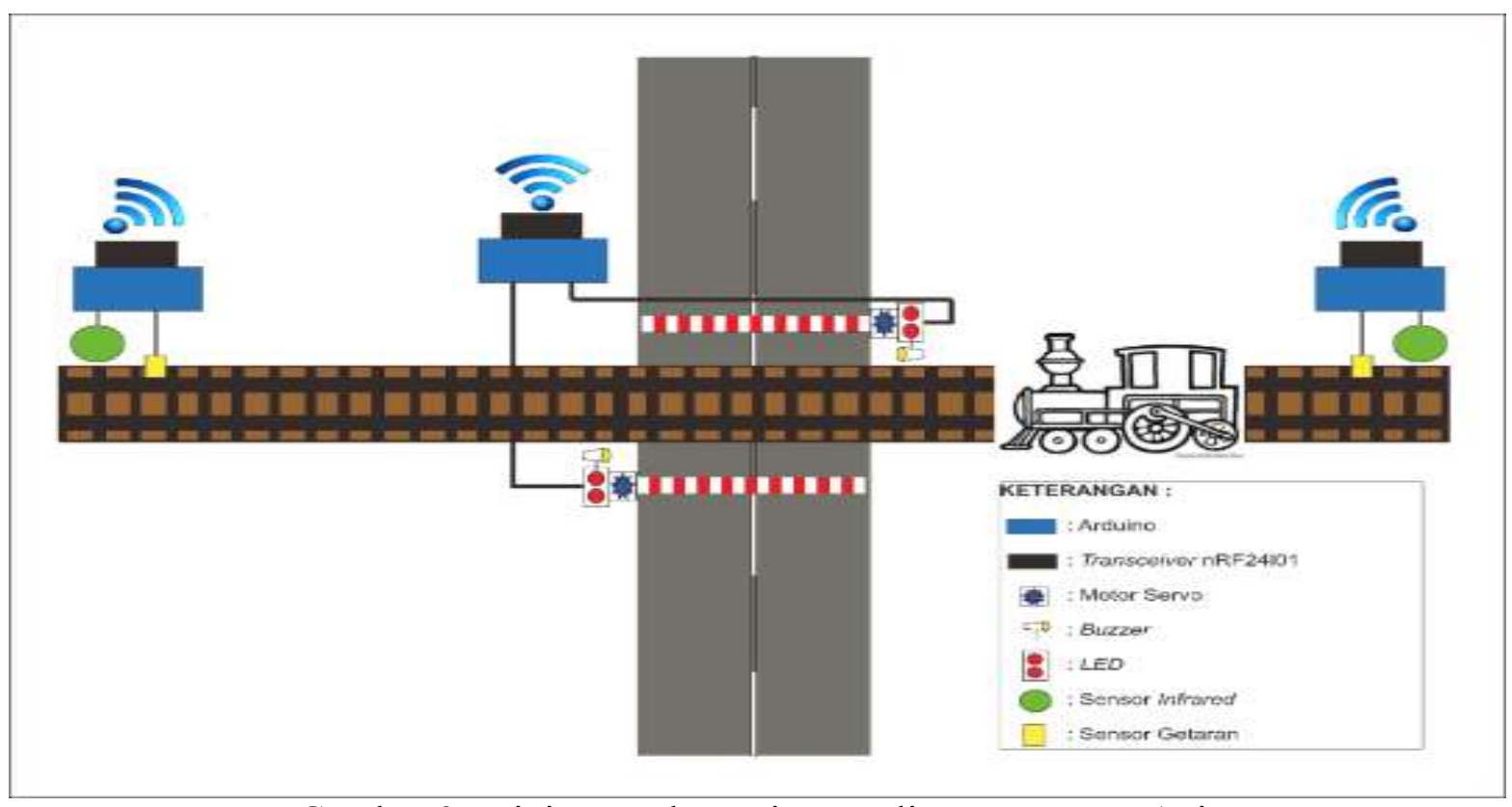

Gambar 9. Miniatur Palang Pintu Perlintasan Kereta Api. 
Tabel 1. Hasil Pengujian Sensor Getaran SW-40

\begin{tabular}{|c|c|c|c|c|}
\hline No & $\begin{array}{c}\text { Putaran } \\
\text { Potensiometer }\end{array}$ & Pengujian ke & Nilai Getaran & $\begin{array}{l}\text { Sensitivitas } \\
\text { Getaran (\%) }\end{array}$ \\
\hline \multirow{5}{*}{1} & \multirow{5}{*}{$0 \%-20 \%$} & 1 & 96.678 & \multirow{5}{*}{$52,76 \%$} \\
\hline & & 2 & 84.056 & \\
\hline & & 3 & 92.188 & \\
\hline & & 4 & 82.753 & \\
\hline & & 5 & 81.443 & \\
\hline \multirow{5}{*}{2} & \multirow{5}{*}{$20 \%-60 \%$} & 1 & 88.317 & \multirow{5}{*}{$47,23 \%$} \\
\hline & & 2 & 72.736 & \\
\hline & & 3 & 72.610 & \\
\hline & & 4 & 80.847 & \\
\hline & & 5 & 76.805 & \\
\hline \multirow{5}{*}{3} & \multirow{5}{*}{$60 \%-100 \%$} & 1 & 0 & \multirow{5}{*}{$0 \%$} \\
\hline & & 2 & 0 & \\
\hline & & 3 & 0 & \\
\hline & & 4 & 0 & \\
\hline & & 5 & 0 & \\
\hline \multicolumn{3}{|c|}{ Jumlah Data } & 828.433 & $100 \%$ \\
\hline \multicolumn{3}{|c|}{ Rata - Rata } & 55.228 & \\
\hline
\end{tabular}

sejauh $80 \mathrm{~cm}$. Sensor infrared yang digunakan pada perancangan sistem ini sebanyak 2 buah. Pada ujicoba sensor pertama, sensor infrared ini hanya mampu mendeteksi obyek sejauh $70 \mathrm{~cm}$.

\subsection{Pengujian Sensor Getaran SW-40}

Pengujian sensor getaran ini berfungsi untuk mengetahui sensitivitas sensor terhadap getaran. Pengujian dilakukan dengan cara mengubah posisi potensiometer yang ada di modul sensor untuk mengetahui pengaruh sensitivitas sensor terhadap getaran. Hasil pengujian disajikan pada tabel

\subsection{Pengujian Jarak Modul Transceiver nRF24101}

Pengujian dilakukan dengan meletekkan receiver pada posisi yang tetap dan mengubah letak transmitter. Pengujian dilakukan dengan membawa transmitter menjauh dari reciever dan memberi sinyal informasi untuk mendapatkan jarak terjauh dari sinyal pengiriman. Dari percobaan didapat jarak terjauh pengiriman data dengan modul ini adalah $940 \mathrm{~m}$. Delay pengiriman data dari transmitter ke receiver ditunjukkan pada gambar 10 . 1.

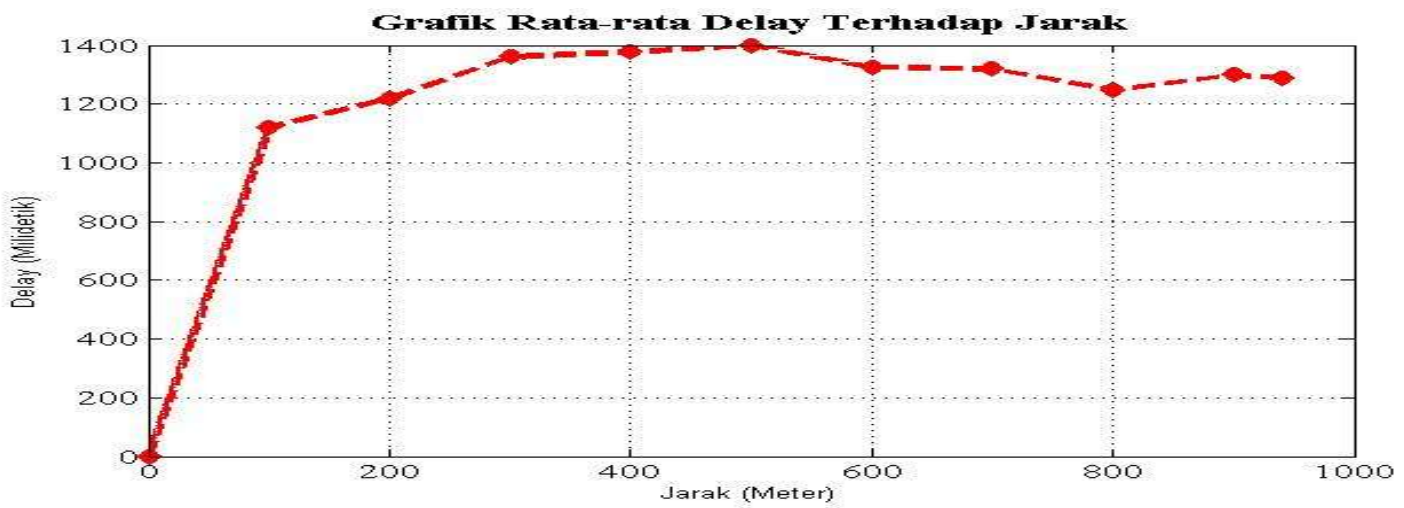

Ganbar 10. Delay Pengiriman Data Menggunakan Modul Wireless nRF24L01. 


\subsection{Pengujian Sistem Keseluruhan}

Pengujian dilakukan dengan menggunakan kereta mainan untuk menguji sensor inframerah dan pemberian getaran pada miniatur untuk menguji deteksi kereta oleh sensor getaran. Dari hasil pengujian didapat sistem berjalan sesuai dengan perancangan awal yaitu dapat menutup dan membuka palang pintu perlintasan kereta api secara otomatis.

\section{KESIMPULAN}

Berdasarkan pada hasil ujicoba yang telah dilakukan, maka dapat diambil kesimpulan bahwa Nilai data yang dihasilkan sensor getaran tidak stabil dan berdasarkan hasil analisa, semakin besar prosentase putaran potensiometer, maka sensitivitas sensor getaran akan semakin berkurang. Pada area terbuka, jarak yang dapat dijangkau oleh transceiver nRF24101+PA+LNA untuk berkomunikasi adalah 940 meter. Semakin jauh jarak transmisi data, maka delay yang dihasilkan akan semakin besar. Secara garis besar sistem sudah bekerja sesuai dengan perancangan awal.

\section{DAFTAR PUSTAKA}

Biswas, S, Bhuiyan, R, Hoque, S, Hasan, R and Khan, T, 2013, American Journal of Engineering Research (AJER), Volume-02, Issue-11.

Deny Setyo, 2015, Pendeteksi Kereta Api Untuk Alarm Perlintasan Rel Dengan Mikrokontroler ARM NUC120, (On-line) Available at http://belajararm.blogspot.com/201 5/01/pendeteksi-kereta-apisebagai.html.

Krishnamurthi, K, Bobby, M, Vidya V and Baby, E, 2015, Sensor Based Automatic Control of Railway Gates, International Journal of Advanced Research in Computer Engineering \& Technology (IJARCET) , Volume 4 Issue 2, February.

Mahdi, A and Zuhairi, A, 2013, Automatic Railway Gate and Crossing Control based Sensors \& Microcontroller, International Journal of Computer Trends and Technology .(IJCTT), Volume 4 issue 7 July.

Muhammad Fayyadh, 2015, Perancangan Sistem Otomatisasi Palang Pintu Kereta Api Berbasis Motion Detection. Teknik Telekomunikasi - Universitas Telkom, Bandung.

P.A. Nusantara, 2012, Implementasi Sistem Palang Pintu Perlintasan Kereta Api Otomatis : Pendeteksi Kereta Api Dengan Sensor Inframerah. Teknik Telekomunikasi - Universitas Telkom, Bandung.

S.R. Oktariza, 2015 Simulasi Sistem Keamanan Palang Pintu Perlintasan Kereta Api Menggunakan LabVIEW. Teknik Elektro Universitas Riau, Pekanbaru. 